\title{
Introdução à Política Florestal
}

\author{
Herbert O. R. Schubart *
}

A região coberta pela floresta amazônica constitui um dos últimos grandes espaços da terra ainda relativamente pouco perturbados pela atividade do homem. No entanto, diante da perspectiva de a população humana do planeta vir a dobrar dentro de uma geração, é óbvio que os recursos naturais encontrados nestes espaços se vejam sob pressão crescente. Evidentemente, a questão fundamental que se apresenta à humanidade, tendo em vista a finitude dos recursos naturais da terra, é a da regulação de suas populações por mecanismos mais inteligentes que as guerras, as catástrofes ou a fome. No trabalho que ora se apresenta, resultado de um esforço coletivo de pesquisadores do Instituto Nacional de Pesquisas da Amazônia, não se trata, é claro, diretamente, deste problema fundamental, mas sim se procura analisar e fornecer subsídios para solucionar os conflitos de interesses em torno dos recursos naturais da Amazônia.

A Amazônia brasileira vem sendo espoliada desde seu descobrimento, situação esta, aliás, válida para o resto do país. O peculiar na Amazônia é que pouquíssimo se fez para converter a riqueza que dela se retirava em desenvolvimento autêntico de suas populações, dandolhe um mínimo indispensável de autonomia comparativamente à outras unidades da Federação.

Ao modelo extrativista, do qual o período da borracha é o paradigma, mas que vem até os dias de hoje seletivamente dizimando espécies como o peixe-boi, o pau rosa, a sorveira, o jacaré, a ariranha, para citar alguns exemplos, sobrepôs-se mais recentemente, a partir de 1966, o modelo de exploração incentivada por benefícios fiscais. É sobretudo a agropecuária na terra firme que se expande nesse período. O que o extrativismo, de um modo geral, tem de insidioso, pois destrói recursos específicos sem destruir a totalidade do tecido ecológico da região, tem a agropecuária incentivada, de berrante e destruidora. Agora são as grandes derrubadas de florestas, as queimadas imensas, que vão consumindo o maior recurso natural da região, que é a própria floresta, substituindo-a por pastagens cujo futuro mais provável é a degradação. Neste período formaram-se 3.500 .000 ha de pastagens, das quais 500.000 ha já estão degradados.

No entanto, talvez se possa dizer que a agropecuária em um ponto teve um aspecto positivo : contribuiu intensamente para a formação de uma consciência ecológica voltada para a Amazônia, não só entre amazônidas, como também em todo o povo brasileiro. Já não eram ape- 
nas a poluição e demais problemas das grandes cidades, que angustiavam o povo; começava-se a destruir também a última grande floresta, a exemplo do que já havia acontecido com a Mata Atlântica; iniciava-se um conflito de interesses entre necessidades reais de preservação da vida selvagem, de recursos vegetais incalculáveis, de solos, de equilíbrios climáticos e de recursos hídricos imensos e necessidades econômicas também reais do país.

Hoje, a agropecuária de terra firme, em região de floresta, vem sendo francamente desestimulada pelo governo, o que é muito louvável. Essa atividade já cumpriu sua missão conscientizadora! Finalmente o interesse volta-se de maneira específica sobre o que talvez seja o maior recurso natural renovável da região : a madeira.

Considerando as dimensões continentais da região, sua tessitura ecológica muito mais diversificada do que se imagina, e os mais diversos interesses e preșsões existentes em torno da Amazônia, criou o governo federal através do Decreto Presidencial N. 83518 , de 29 de maio de 1979 um Grupo de Trabalho Interministerial, para apresentar dentro de 120 dias ao Congresso Nacional um projeto de lei estabelecendo uma política florestal para a Amazônia brasileira. Para realizar tarefa tão abrangente e importante, contou o Grupo de Trabalho com subsídios fornecidos por todos os órgãos atuantes na Amazônia.

Pela primeira vez, consultam-se as Universidades e Institutos de Pesquisas da região no sentido de opinarem e fornecerem subsídios científicos e técnicos que informem uma decisão governamental tão importante para o futuro da Amazônia. É essa justamente a função das Universidades e Institutos de Pesquisas na sociedade. Aliás, aquì não deixa de ser interessante lembrar que o INPA foi criado, como uma reação a anseios de internacionalização da Amazônia, pelo Decreto Lei N. ${ }^{\circ} 31.672$, de 29 de outubro de 1952, no governo do Presidente Getúlio Vargas, tendo por finalidade "o estudo científico do meio físico e das condições de vida na região amazônica, tendo em vista o bem-estar humano e os reclamos da cultura, da economia e da segurança nacional".

Percorrendo-se o índice dos trabalhos que compõem este documento, conclui-se que a orquestraçăo de muitos talentos e opiniões produz um resultado final muito mais em harmonia com a realidade da vida prática do que o virtuosismo de qualquer talento ou opinião isolados. Entre os autores, talvez se encontrem, desde aquele que preconiza a intocabilidade da Amazônia, até aquele que propõe sua exploraçäo total, ambos com excelentes argumentos, porém ambos alienados da vida prática.

A liberdade de opinião, o debate e o respeito mútuo que constituem a conditio sine qua non da universalidade caracterizaram de maneira admirável as reuniões para a elaboração deste documento, garantindo uma proposta final bem equilibrada entre aqueles extremos já mencionados. 
Se eu tivesse que apontar as conclusões mais importantes a que se chegou, neste documento, o que é realmente difícil, mencionaria em primeiro lugar o fato de que a extração da madeira existente na floresta não apresenta dificuldades tecnológicas maiores (considere-se por exemplo as perspectivas de exaustão deste recurso na Malásia e Africa), porém não se conhece como explorar economicamente uma floresta tropical heterogênea de modo sustentável, isto é, sem destruir permanente o caráter da floresta como tal. Neste sentido, a floresta tropical é um recurso natural não renovável se derrubada em grandes extensōes; apenas alguns elementos dentro da floresta podem ser manejados de maneira renovável. Daí resulta, em segundo lugar, a seguinte recomendação : a única maneira de garantir-se a exploração não predatória da floresta tropical será deixar a cargo da empresa particular interessada na exploração a responsabilidade pela regeneração do recurso explorado. Só assim a exploração seria feita com todos os cuidados necessários de tal modo que diminuisse os custos de regeneração da floresta, garantindo a economicidade do projeto. Ao Estado competiria a definição da política, a recomendação das técnicas a serem utilizadas e a fiscalização das operações das empresas. Em terceiro lugar, constata-se uma enorme necessidade de pesquisas no campo da ecologia e manejo de florestas tropicais. 